Special Issue on Business and Organization Research

\title{
Destination Personalities of Alacati and Ayvalik in Turkey: Consumer Perceptions of a Summer Holiday
}

\author{
Türkiye'de Alaçatı ve Ayvalık'ın Destinasyon Kişilikleri: Tüketicilerin Yaz \\ Tatili Algısı
}

\author{
Petek TOSUN, Turkey, petektosun@yahoo.com \\ Orcid No: 0000-0002-9228-8907 \\ Merve AKAR, Maltepe University, Turkey, merveakar@maltepe.edu.tr \\ Orcid No: 0000-0003-2470-7919
}

\begin{abstract}
In 2018 summer, Alaçatı and Ayvallk have been listed among the top cities that are preferred as tourism destinations for local tourists. These destinations have been popular for tourists in the last decade and Turkish tourists increasingly prefer local destinations for their summer holidays because of the devalued Turkish lira. Attracting tourists is among the primary goals for tourism marketers, and consequently understanding customer perceptions regarding destinations is one of the key factors to achieve this goal. In this context, the purpose of this study is to examine the destination personalities of Ayvalı and Alaçatı and compare them in terms of destination personality dimensions. In a quantitative research design, respondents $(n=191)$ have been asked about their perceptions about the destination personalities of Alaçatı and Ayvalık, in which they compare the two destinations on a 5 Point-Likert scale. Destination personalities have been examined within the conceptual framework of destination personality dimensions, which are, sincerity, excitement, and conviviality. In addition, respondents have answered a question by writing their opinions about "a great summer vacation" with a few words, which have been analyzed by content and cluster analyses, aiming to have a deeper understanding about the consumer perceptions about their summer vacations. Significant differences have been found between the destination personality dimensions of Ayvalık and Alaçatı. Ayvalık is perceived as sincerer and more convivial than Alaçatı, whereas Alaçatı is perceived as more exciting than Ayvalı. Regarding their expectations from their summer holiday, consumers have been grouped into 4 clusters such as; (1) fun, excitement, and activity oriented, (2) travelling and exploring oriented, (3) family and friends oriented, (4) relaxation, comfort, and silence-oriented consumers. There is not a significant difference among clusters regarding the perceived destination personalities of Ayvalık and Alaçatı. This study aims to contribute to researchers not only by implementing destination personality research in the Turkish context, but also by extending the existing knowledge by assessing destination personality concept together with the consumers' descriptions of an idealized summer vacation. Moreover, findings of the study will be beneficial for marketing activities of tourism agencies, hospitality industry, and local governments.
\end{abstract}

Keywords: Destination Personality, Destination Marketing, Brand Personality, Brand Image

Öz: Alaçatı ve Ayvalık, 2018 yazında yerli turistler tarafindan en çok tercih edilen tatil destinasyonları arasında yer almıştır. Bu destinasyonlar, turistler için son 10 yıldır popülaritesini korumakta olup, özellikle son dönemde Türk lirasının döviz karşısındaki değer kaybı sonucunda yerli turistler yaz tatilleri için daha çok yurt içi destinasyonları tercih etmektedir. Turizm pazarlamasında turist kazanımı birincil hedefler arasında yer aldığından destinasyonlara ilişkin tüketici algllarının incelenmesi son derece önemlidir. Bu kapsamda, bu çallşmanın amacı Ayvalık ve Alaçatı'nın destinasyon kişiliklerinin incelenmesi ve destinasyon kișiliklerinin alt boyutlarının karşılaştırılmasıdır. Araştırma kapsamında tüketiciler (n=191) Alaçatı ve Ayvalık hakkındaki anketi yanttlayarak, bu iki beldenin destinasyon kişiliğini 5 'li Likert ölçek ile oluşturulmuş soru formunda karşılaştırmıştır. Destinasyon kişilikleri, samimiyet, canlılık ve eğlenceden oluşan alt boyutlar kapsamında incelenmiștir. Buna ek olarak tüketicilerin yaz tatiline ilişkin düşüncelerinin derinlemesine anlaşılabilmesi için kendilerinden "harika bir yaz tatili" için beklentilerini yazmaları istenmiş ve bu soruya verecekleri yanıtlar içerik analizi ile incelenmiştir. Araştırma sonucunda Ayvalık ve Alaçatı'nın destinasyon kişilikleri arasında anlamlı farklılıklar tespit edilmiştir. Ayvalık daha samimi ve eğlenceli olarak algılanırken, Alaçatı daha canlı olarak algılanmaktadır. Yaz tatilinden beklentilerine göre tüketiciler 4 gruba ayrllmıştır; (1) eğlence, heyecan ve aktivite arayanlar, (2) seyahat etmek ve keşfetmek isteyenler, (3) aile ve arkadaş odakl tüketiciler, (4) konfor, sessizlik ve sakinlik arayan tüketiciler. Bu tüketici grupları arasında, Ayvalık ve Alaçatı'nın algılanan destinasyon kişilikleri arasında anlamlı bir fark tespit edilememiştir. Bu çalışma, destinasyon kişiliği çalışmalarını Türkiye'de uygulayarak araştırmacılara katkı sağlamayı amaçlamakta, buna ek olarak tüketicilerin ideal bir yaz tatili için düşüncelerini destinasyon kişiliği kavramı ile birlikte değerlendirerek konu hakkındaki mevcut bilgi birikimini genişletmeyi amaçlamaktadır. Araştırma sonuçlar turizm acentelerinin, turizm ve konaklama sektörünün ve yerel yönetimlerin pazarlama yöneticileri için de faydalı olacaktır.

Anahtar Kelimeler: Destinasyon Kişiliği, Destinasyon Pazarlaması, Marka Kişiliği, Marka İmajı

\section{Introduction}

Due to globalization and technological inventions, leisure activities have altered and addressed all types of people who have limited time and affordability. Moreover, transportation services have become cheaper and availability of knowledge has increased compared to the past. Since working conditions have become difficult and stressful for individuals, holiday entitlement has transformed into an actual need from a luxurious activity (Kozak \& Bahçe, 2012; Kerr et al., 2012). As a result of rising income levels, the concept of a "holiday" has gained more meaning even for a few days long (Dilber, 2007). Thus, they prefer to escape their routine business lives and spend their limited leisure time doing several different activities by paying even higher prices. Also, they are more willing to discover new places with their friends or family. For all of such decisions, destination personality is a key element as it differentiates places with regard to their brand personalities (Kaplan et al., 2010).

Makale Gecmiși / Article History

Başvuru Tarihi / Date of Application : 2 Ekim / October 2019

Kabul Tarihi / Acceptance Date : : 15 Kasım / November 2019 
The tourism industry is the combination of various sectors including different businesses such as transportation services, hotels, restaurants, recreation centers, clubs, theme parks, and many more, and therefore it is among the prominent industries in the Turkish economy (Kozak \& Bahce, 2012). As a result of the accelerated urbanization in Turkey, people who spend long hours at work prefer to visit sea coasts to rest in nature and get relief from their stress particularly in the Aegean region in Turkey. In addition to local tourists, the increased level of information sharing via social media channels and natural beauty of the Aegean region attract foreign tourists who prefer to get rest by sunbathing, swimming and tasting delicious nostalgic foods.

According to the Hoteliers Federation of Turkey, the Aegean Region including Ayvalık and Alaçatı districts has experienced significant demand from local tourists (Alp, 2018). The Republic of Turkey Ministry of Culture and Tourism has announced the number of local tourist arrivals for Ayvalik as more than 115.000 and Çeşme district -that includes Alaçat1- as more than 286.000 in 2018 (KTB, 2019). These destinations have been popular for tourists in the last decade and Turkish tourists increasingly prefer local destinations for their summer holidays because of the devalued Turkish lira (NTV, 2019). In addition to high number of tourists, both destinations are considered as prominent small-scale destination brands that have further potential for contributing to the tourism in the Aegean region (Çoban \& Süer, 2018; İçöz, 2013). For tourism destinations, destination marketing is the source of achieving competitive advantage through creating customer satisfaction and reaching the target market, and destination brand personality is a major element for creating a competitive advantage in the context of destination marketing (Güzel et al., 2018). Since attracting tourists is the most important goal for tourism marketers, it is not enough to provide high-quality service in touristic places. Marketers have to differentiate their services and products by creating a brand image about the destination (Türkmen \& Köroğlu, 2017). Destination personality is a source of competitive advantage since it enables marketers to position a destination according to the feelings it generates, meanings, and its ability to offer consumers unique experiences (Dickinger \& Lalicic, 2016).

As an appealing touristic country with various traveling options, there is some research focused on the destination personalities of specific destinations in Turkey (Çetinsöz \& Atsan, 2019; Güzel et al., 2018). Ayvalık and Alaçatı are among prominent destinations that have been studied in the destination marketing context since they have a rich spectrum of appealing elements for tourists such as beautiful sea, nature, local food festivals or authentic bazaars (Çoban \& Süer, 2018; İlban \& Kömür, 2019). Destination personalities evoke rich associations in a broad spectrum, so they are strong elements for differentiation and important for several stakeholders such as municipalities, non-governmental organizations, and tourism agencies (Kaplan et al., 2010). Moreover, destination personality dimensions have an important effect on destination satisfaction and destination loyalty such as revisiting intentions (Chi et al., 2018). Within the context of destination marketing, this study aims to explore whether a difference exists between the destination personalities of Ayvalık and Alaçatı. In addition, the perceived destination personalities of these two places are compared based on the summer vacation preferences of different consumer groups. The findings contribute to researchers not only by implementing destination personality research in the Turkish context but also by extending the existing knowledge by assessing destination personality concept together with the consumers' descriptions of idealized summer vacation. So, the findings of the study will be beneficial for the marketing activities of tourism agencies, the hospitality industry, and local governments.

The study is organized as follows; in the conceptual background section, brand image, brand personality, and destination personality dimensions are explained and research questions are presented. Then the methodology is explained and research results are illustrated. The study ends with the discussion and conclusion sections.

\section{Conceptual Background}

\subsection{Brand Image and Destination Image}

The type of image portrayed by a destination will influence the types of visitors or tourists who will be attracted to the touristic products or services offered. Brand or destination image is vitally important for a touristic place in the tourism industry, therefore it's better to have a differentiated image that is consistent with the type of consumers that they want to attract. Brand image reflects a brand's position in an individual's mind and this position is built among many information floods and associations. Therefore, destination image is the combination of promotional assets (travel brochures, billboards), opinions of other people that constitute the social environment of tourists (family, friends, travel agents), traditional media (newspapers, TV, books, movies), social media (Facebook, Instagram, bloggers, influencers) and internet comments (websites, Booking.com, Trivago.com, etc.). In addition, the experience gained by visiting the destination will build a real destination image on a tourist's mind (Echtner \& Ritchie, 1991). As a result, destination image is explained as "the sum of beliefs, ideas and impressions that a person has of a destination" (Zhou \& Deng, 2012).

Tourism marketers need to build a positive and interesting destination image to attract tourists to their place. Furthermore, every destination has its self-identity with its historical places, hospitality features or natural beauties (Güzel, et al., 2018). This self-identity takes place in the tourists' minds, resulting in the formation of destination images and attributing the characteristics of people to destinations. Destination image is a combination of cognitive and affective elements. While the cognitive element refers to one's beliefs and knowledge about the physical features of a destination, the affective component is related to a destination's valuation of the effective quality of feelings towards attributes that encompassed by the environment. In the literature, tourists' satisfaction, behavior, and choice are affected by destination image directly (Zhou \& Deng, 2012). 


\subsection{Brand Personality and Destination Personality}

Brand personality makes products or services more distinguishable than their rivals. Therefore, consumers who are aware of the product or service in the market easily, and this affects not only consumers' purchasing behavior but also their future decision-making process (Türkmen \& Köroğlu, 2017). Especially in highly competitive markets, products or services need to be associated with human personality traits by their distinctive attributes in order to describe themselves better than their competitors (Souiden et al., 2017). According to Aaker (1997) brand personality refers to "the set of human characteristics associated with a brand". From this perspective, one of the most important meanings of a brand is the symbolic benefits that consumers perceive rather than functional utilities provided by the particular brand. Therefore, consumers prefer the brands which have the same personality traits with themselves since they can represent their real and ideal selves by completing their social identity using these brands (Wang \& Yang, 2008). As a consequence, brand personality impacts consumers' brand preferences during their buying process by establishing a strong emotional link between the consumer and product (Matzler et al., 2016; Ekinci \& Hosany, 2006).

Destination personality has emerged with the idea that touristic destinations can have brand personality traits in the same way as products and services (Ülkü et al., 2017). To the best of our knowledge, destination personality is defined as "the set of human characteristics associated with a tourism destination" (Hosany et al., 2006). As mentioned above, in the tourism industry, as a result of cheaper transportation costs and globalization, competition has become international. For instance; Turkey's Aegean region has become a rival to the Greek Islands located in the Aegean Sea. Therefore, competition between tourist destinations has increased and become more challenging. Moreover, touristic destinations should position themselves with exclusive features that are different from other destinations in order to enhance their preference by tourists or visitors in both countries. Tourism marketers increasingly adopt brand personification strategies to create positive consumer reactions (Matzler et al., 2016). Additionally, symbolic values can be created from the tourists' point of view and created through an original identity by using destination personality (Türkmen \& Köroğlu, 2017). As a result, tourists can distinguish destinations more easily and may create a positive image about destinations on account of destination personality. Thus, tourists establish a strong connection with the destination and willing to visit there again (Ülkü et al., 2017).

\subsection{Relationship between Destination Image and Destination Personality}

While brand image refers to both the functional and symbolic benefits of a brand, brand personality only refers to the symbolic function of a brand (Zhou \& Deng, 2012). As mentioned above, people set up an emotional link between themselves and products based on their symbolic value. As a result, specific brand users feel more valuable, sophisticated and distinguished compared to nonusers or non-visitors (Ekinci \& Hosany, 2006). However, while perceptions of human traits refer to a person's basic behaviors such as physical features, attitudes or demographic characteristics, perceptions of destination can be shaped as personal traits by the marketers and this may influence tourist's evaluations during contact with the place (Plummer, 1985). Due to experience-based tourism activities, when tourists find something similar to their personality traits, they will complete their self-image and will be more satisfied with their tourism experience. Destinations send lots of messages or images to tourists and they interpret a kind of "behavior" that represents the destination directly or indirectly.

The set of personality traits including citizens of the city, hotel employees, restaurants and tourism activities for tourists may directly be related to a destination (Aaker, 1997). Furthermore, human characteristics can be attributed through marketing strategies of the city such as advertising, value pricing, famous people of the country, and popular influencers of social media. Additionally, similar to products or services, touristic destinations also represent symbolic values and personal traits which include tangible and intangible attributes of the city. These components can be values, histories, events, and feelings related to visitor attractions, hotels, and people (Ekinci \& Hosany, 2006).

Particularly in the tourism industry, the destination image is identified as a key component of destination and tourist loyalty (Hosany et al., 2006). Destination image acts as a key to form expectations about destination brand quality and influences consumers' perceptions of destinations (Dedeoğlu et al., 2019). Furthermore, destination image consists of all types of city or region related concepts, while destination personality refers to more emotional components of the destination image (Hosany et al., 2006). It can be interpreted that whereas destination image is a kind of a generic term that combines everything related to a destination and a reflection of tourist's mind, destination personality consists of values and experiences that tourists feel. In addition, building a destination image contributes marketing activities in communicating appropriate marketing messages regarding the target consumers' needs and expectations. In this context, distinctive touristic brands assume that destination personality is one of the most important indicators of tourist purchasing behavior (Chen \& Phou, 2013).

\subsection{Comparison of Alaçatı and Ayvalık}

Alaçatı and Ayvalık are very popular destinations for summer vacations in the Aegean region of Turkey. Both of them have beautiful nature and beaches where tourists can relax and escape from daily routine or work-related problems. Additionally, they have also small famous boutique hotels which make visitors happy. People not only prefer Alaçatı and Ayvalık for sea, sand, and sun, but also an unforgettable summer vacation experience that they have never lived before. 
Furthermore, Alaçatı and Ayvalık have delicious Mediterranean cuisine that tourists want to taste such as olive oil dishes and fresh fish types.

Ayvalık is a small district which is located in Balıkesir in Turkey. People prefer to visit Ayvalık because it has a unique history from Ottoman Empire and ancient times. There are a lot of tourist attractions such as churches, mosques and old houses that need to be visited by tourists. Cunda Island is also very famous for its natural beauty and clean blue sea (Ayvalık Belediyesi, 2019). Although they are located close to each other and similar in terms of natural beauty and cousine, Alaçatı is a more popular destination compared to Ayvalık. Due to some social media influencers, celebrities and popularity of its fantastic beaches and nightlife, many domestic and foreign tourists prefer to spend their summer vacation in Alaçatı. Moreover, Alaçatı also has a windy sea available for wind-surfers. Thus, many people who like windsurfing choose Alaçatı for competitions and its successful windsurf schools (Yolda, 2018). Another distinguishing feature of Alaçatı is its unique small streets with blue and white-colored houses (Tokmakoğlu, 2017). Tourists like to float around and shop in various small boutiques in the convivial atmosphere of Alaçatı.

As mentioned above, both Alaçatı and Ayvalık contain various summer experience within themselves. Native and domestic tourists would like to experience these destinations during their trips. They can relax with clean sea, sand, and sun, taste products of the delicious Mediterranean kitchen, experience historical places, have some fun on the beaches day and night, and wind-surf with professionals. Alaçatı and Ayvalık can provide all tourists what they desire during their summer holiday.

Ayvalık and Alaçatı are two destinations that deserve attention for research since they are similar to each other in terms of location and natural beauties, but they are very different from each other in terms of social life and visitor profile. The popularity of Alaçatı has increased in the last decade, mainly due to its famous Turkish visitors, and celebrities. On the other hand, Ayvalık has maintained its appeal as a peaceful small town with beautiful sea and nature. So, the first research question of this study has been formed as; "RQ1: Do destination personalities of Alaçatı and Ayvalık differ from each other?" Accordingly, the research hypotheses have been formed in alignment with the dimensions of destination personality construct, which are sincerity, excitement, and conviviality as follows (Hosany et al., 2006);

H1a: Destination personalities of Alaçatı and Ayvalık have a significant difference in sincerity.

H1b: Destination personalities of Alaçatı and Ayvalık have a significant difference in excitement.

H1c: Destination personalities of Alaçatı and Ayvalık have a significant difference in conviviality.

The abovementioned increase in the tourist traffic of Alaçatı has influenced the economic and social patterns of the town. Alaçatı has been a peaceful and sophisticated place which has been appealing for the highly educated society of Istanbul, however, its increased popularity is now attracting tourists from various backgrounds who want to visit Alaçat1 for its appealing night-life in weekends. Some experts point out that this increased popularity may push the initial visitors who prefer to have distinguished experiences away from Alaçatı and make them seek for "unexplored" beauties in Turkey. If such change occurs, meaning a shift down in the popularity of Alaçatı, local entrepreneurs and the general economic and social life will be affected. Hedonic value perceptions of consumers are important elements of destination brands (Dedeoğlu et al., 2019). In this context, studying consumers' expectations in the context of destination personality is important not only for researchers but also for marketing practitioners. Having a deeper understanding of consumer expectations and asking them about their definition of "a great summer vacation" will help to interpret consumers' perception of destination personalities. So, the second research question of this study is formed as; "RQ2: Is there a difference in perceived destination personalities of Ayvalık and Alaçatı, depending on summer vacation preferences of different consumer groups?"

\section{Research Method}

191 valid questionnaire forms were obtained by convenience sampling method in Istanbul. Participants consisted of students (48\%), white-collar workers (41\%), non-working individuals (4\%), and owners of small businesses $(3 \%)$. The age of the participants ranged between 18 and 60, with a mean of 28 and a standard deviation of $9.6 .58 \%$ of the participants were female, and $42 \%$ were male. The distribution of education status of the participants was as follows; $43 \%$ high-school, $30 \%$ undergraduate, and $27 \%$ graduate. Since the questionnaire form was quite short and participants were mainly students and young professionals, only 9 forms were eliminated because of missing data or other problems. $8.5 \%$ of the participants stated that they cannot go on a vacation each year, $60 \%$ of the participants stated that they go on a vacation once/twice a year, and $30.5 \%$ of the participants stated that they go on a vacation more than 3 times a year. On a 5-point Likert scale, in which " 5 " indicated "very important" and " 1 " indicated "not important"; $60 \%$ of the participants stated that their holiday is "5-very important" for them, where $26 \%$ and $11.5 \%$ of the participants signed " 4 " and " 3 ", respectively.

\section{Analysis}

\subsection{Analyzing the Differences between the Destination Personalities of Ayvalık and Alaçatı}

In the first stage of the analysis, two factor analyses with principal component extraction and Varimax rotation were conducted for destination personality items of Ayvalık and Alaçatı. 
"Successful" item under the sincerity dimension and "original" item under the excitement dimension had low factor loadings, so they are eliminated from the factor analysis. The Keiser-Meyer-Olkin (KMO) measures of sampling adequacy were 0.858 for Alaçatı (Bartlett's test $p=0.00$ ) and 0.821 for Ayvalık (Bartlett's test $p=0.00$ ). Explained cumulative total variance values are $69 \%$ for Alaçatı and $67 \%$ for Ayvalık. The scale items were loaded to factors in alignment with the original destination personality scale (Hosany et al., 2006). The scales are reliable since Cronbach's Alpha values are higher than 0.6 . The results of the factor and reliability analyses are illustrated in Table 1.

Table 1. Overall Results of Factor Analyses and Reliability Analyses

\begin{tabular}{|c|c|c|c|c|c|}
\hline \multirow[t]{2}{*}{ Scale Items } & & \multicolumn{2}{|l|}{ Ayvalık } & \multicolumn{2}{|l|}{ Alaçatı } \\
\hline & & Factor Loadings & Cronbach's Alpha & Factor Loadings & Cronbach's Alpha \\
\hline \multirow[t]{5}{*}{ Sincerity } & Sincere & 0.823 & 0.841 & 0.779 & 0.858 \\
\hline & Intelligent & 0.710 & & 0.616 & \\
\hline & Reliable & 0.808 & & 0.831 & \\
\hline & Wholesome & 0.714 & & 0.777 & \\
\hline & Down to earth & 0.729 & & 0.769 & \\
\hline \multirow[t]{3}{*}{ Excitement } & Daring & 0.838 & 0.894 & 0.748 & 0.809 \\
\hline & Exciting & 0.933 & & 0.799 & \\
\hline & Spirited & 0.888 & & 0.863 & \\
\hline \multirow[t]{3}{*}{ Conviviality } & Friendly & 0.730 & 0.781 & 0.813 & 0.807 \\
\hline & Charming & 0.837 & & 0.791 & \\
\hline & Family oriented & 0.734 & & 0.596 & \\
\hline
\end{tabular}

As a result of factor analysis, items are recoded as new variables in SPSS for each dimension of destination personality. For analyzing different personality associations in a consumers' mind regarding Ayvalık and Alaçatı, pairedsamples t-tests were conducted for each destination personality dimension. The destination personalities of Ayvalık and Alaçatı are perceived as significantly different from each other. The results are illustrated in Table 2.

Table 2. Paired-samples t-test Results

\begin{tabular}{lllll}
\hline & $\begin{array}{l}\text { Mean } \\
(\text { Ayvalık })\end{array}$ & $\begin{array}{l}\text { Mean } \\
(\text { Alaçatı })\end{array}$ & $\begin{array}{l}P \\
\text { value }\end{array}$ & Comment \\
\hline Sincerity & 3.83 & 3.52 & 0.00 & Ayvalık is perceived as sincerer than Alaçatı. \\
\hline Excitement & 3.29 & 4.43 & 0.00 & Alaçatı is perceived as more exciting than Ayvalık. \\
\hline Conviviality & 4.09 & 3.72 & 0.00 & Ayvalık is perceived as more convivial than Alaçatı. \\
\hline
\end{tabular}

As a result of these analyses, hypotheses $\mathrm{H} 1 \mathrm{a}, \mathrm{H} 1 \mathrm{~b}$, and $\mathrm{H} 1 \mathrm{c}$ were failed to be rejected. There were significant differences between Ayvalık and Alaçatı in terms of destination personality dimensions. Ayvalık was perceived as sincerer and more convivial than Alaçatı, whereas Alaçatı was perceived as more exciting than Ayvalık.

As control variables, participants were also asked whether they have seen Ayvalık and Alaçatı or not. 79\% $(\mathrm{n}=151)$ and $77 \%(\mathrm{n}=147)$ of the participants have seen Ayvalık and Alaçatı before, respectively. 66\% $(\mathrm{n}=126)$ of the participants have seen both destinations, where $10 \%(n=19)$ of them have not seen either of them. When the perception of participants about destination personalities was analyzed by independent t-tests, it is found that consumers who have not seen Ayvalık before find it sincerer and more convivial whereas there was no difference between the perceptions of two groups regarding the excitement dimension. On the other hand, there was no difference between the perceived destination personality of Alacati between consumer groups who have seen and haven't seen Alacati before. The results of the independent t-tests are summarized in Table 3.

Table 3. Independent t-test Results

\begin{tabular}{llllll}
\hline & & $\begin{array}{l}\text { Have seen } \\
\text { before }\end{array}$ & $\begin{array}{l}\text { Have not seen } \\
\text { before }\end{array}$ & $\begin{array}{l}P \\
\text { value }\end{array}$ & Comment \\
\hline Ayvalık & Sincerity & 3.76 & 4.01 & 0.01 & $\begin{array}{l}\text { Consumers who have not seen Ayvalık before } \\
\text { find it sincerer. }\end{array}$ \\
\cline { 2 - 6 } & Excitement & 3.25 & 3.47 & 0.3 & $\begin{array}{l}\text { There is not a significant difference between } \\
\text { consumers' perceptions of excitement. }\end{array}$ \\
\hline
\end{tabular}


Tosun, P., Akar, M. / Journal of Yasar University, 2019, 14 (Special Issue), 82-91

\begin{tabular}{|c|c|c|c|c|c|}
\hline & Conviviality & 4.04 & 4.29 & 0.04 & $\begin{array}{l}\text { Consumers who have not seen Ayvalık before } \\
\text { find it more convivial. }\end{array}$ \\
\hline \multirow[t]{3}{*}{ Alaçatı } & Sincerity & 3.55 & 3.41 & 0.3 & \multirow{3}{*}{$\begin{array}{l}\text { There is not a significant difference between } \\
\text { perceptions of consumers who have and have } \\
\text { not seen Alacati before. }\end{array}$} \\
\hline & Excitement & 4.44 & 4.40 & 0.7 & \\
\hline & Conviviality & 3.73 & 3.66 & 0.7 & \\
\hline
\end{tabular}

\subsection{Comparing the Perceived Destination Personalities among Customer Groups}

The second purpose of this research was to have a deeper understanding of consumer expectations from summer vacation, and exploring whether a difference in perceived destination personalities of Alaçatı and Ayvalık exists among various consumer segments. The questionnaires had an open-ended question that requested participants to write their expectations regarding a great summer holiday. 175 of 191 participants answered this open-ended question. Missing values are eliminated from the content analysis.

Content analysis was used to analyze the responses. First, the answers were coded in Excel according to the themes emerged from data. Themes were assigned as categories and each case was coded as either " 0 " or " 1 " across each category. If a consumer has written "Enjoying sun and beach with my friends"; frequencies of "sea, sun \& nature" and "family \& friends" categories were coded as " 1 ", and frequencies of other categories were coded as " 0 ". The results of the content analysis are illustrated in Table 4.

Table 4. Consumers' Expectations from a Summer Holiday

\begin{tabular}{lcc}
\hline Category & Number of Cases & Percentage of Cases $(n=175)$ \\
\hline Relax, Comfort, \& Silence & & $54.3 \%$ \\
Fun, Excitement, \& Activity & 95 & $35.4 \%$ \\
Sea, Sun \& Nature & 62 & $29.1 \%$ \\
Culture \& Traveling & 51 & $28.6 \%$ \\
Family \& Friends & 50 & $24.0 \%$ \\
\hline
\end{tabular}

In order to obtain meaningful consumer groups regarding their expectations from a summer holiday, a cluster analysis was performed in SPSS. Since content analysis revealed consumer expectations as binary (0-1) variables, a twostep cluster analysis, which enables the analysis of both categorical and continuous variables to find hidden patterns in data and determines the optimum number of clusters, was conducted (Şchiopu, 2010). Two-step cluster analysis can be used for datasets with sample size close to or higher than 200 and turns out good results even if data is not normally distributed (Trpkoval \& Tevdovski, 2009). Researchers can conduct cluster analyses with sample sizes smaller than 200 (Bergman et al., 2012; Nguyen \& Bouchard, 2010). Convenience sampling with small sample sizes is comparable to some previous studies on destination personality (Souiden et al., 2017). It is generally accepted that the number of variables to calculate clusters must meet the criteria of $2 x<n$, where $x$ equals the number of variables used in the cluster analysis (Dolnicar, 2002). Since there were 175 cases, the number of variables to calculate clusters could not exceed 7 $(27=128)$. The categories obtained from the content analysis and additionally "age" as a demographic variable were used to calculate clusters. With these 6 inputs, 3 clusters were obtained with a fair level of separation robustness, where "sea, sun \& nature" and "age" variables could not be identified as important predictors. Other similar tests resulted in models with a poor or fair fit, but they were beneficial in achieving determining important predictors. The final cluster analysis that was conducted by using 4 predictors, which were "family and friends", "fun, excitement, activity", "culture, traveling", and "relax, comfort, silence", resulted in good statistical fit, relatively important predictors, and optimum cluster sizes. The cluster model showing the measure of cohesion and separation, and cluster sizes are illustrated in Figure 1.

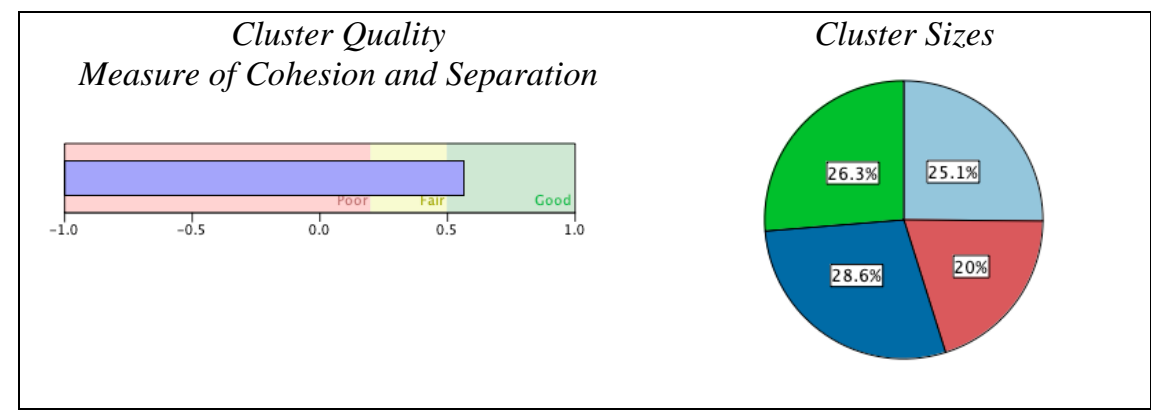

Figure 1. Cluster Model Summary 
The first cluster included 44 consumers $(25.1 \%$ of the sample) who were fun, excitement and activity-oriented consumers. The second cluster included 35 consumers ( $20 \%$ of the sample) whose expectations included traveling and exploring different cultures. The third cluster consisted of 50 consumers ( $28.6 \%$ of the sample) and their distinguishing expectations are preferring to have their vacation together with their family and friends. The final cluster included 46 consumers ( $26.3 \%$ of the sample) who were relaxation, comfort, and silence-oriented consumers.

Regarding the second research question, differences among destination personalities perceived by clusters were analyzed by one-way ANOVA. The significance of ANOVA for each cluster was greater than the reference significance value ( $>0.05$ ), so the perceived destination personalities of Ayvalık and Alaçatı did not differ significantly for any of the clusters. The ANOVA results are illustrated in Table 5.

Table 5. ANOVA Results for Differences among Clusters

\begin{tabular}{llll}
\hline Destination personality dimension & $\begin{array}{l}\text { Levene } \\
\text { Statistic }\end{array}$ & $\begin{array}{l}\text { Significance of } \\
\text { ANOVA }\end{array}$ & Difference among clusters \\
\hline Sincerity of Ayvalı & 0.50 & 0.51 & \\
Sincerity of Alaçatı & 0.43 & 0.91 & No difference \\
Excitement of Ayvalı & 0.58 & 0.51 & \\
Excitement of Alaçatı & 0.28 & 0.45 & \\
Conviviality of Ayvalık & 0.98 & 0.39 & \\
Conviviality of Alaçatı & 0.36 & 0.55 & \\
\hline
\end{tabular}

\section{Discussion}

Significant differences have been found between the brand personality dimensions of Ayvalık and Alaçatı. Ayvalık is perceived as sincerer and more convivial than Alaçatı, whereas Alaçatı is perceived as more exciting than Ayvalık. These results show that although these two beautiful destinations are located close to each other and share similar natural beauty, social life and visitor profile has extended to create significant differences between their perceived destination personalities. This finding is supporting the study of Kaplan et al. (2010) since destination personalities can differentiate places in a similar manner with classic product brands. Destination personality dimensions strongly influence destination satisfaction and the perceived congruity between the consumer and the destination's personalities, and accordingly destination personality dimensions are influential on consumers' revisit and referral intentions regarding a destination (Chi et al., 2018).

Sincerity dimension included items such as "reliable, wholesome, and down to earth" and conviviality dimension included items such as "friendly and family-oriented", so these attributes have been more strongly associated with Ayvalık, which is a quieter place than Alaçatı. On the other hand, the popularity of Alaçatı, its dynamic beaches, and relatively richer night entertainment options may have led consumers to perceive it as more exciting than Ayvalık. Indeed, Ayvalık has been a more established and older destination for summer vacation, for even investing in a summerhouse, especially for white-collar workers of big cities. However, Alaçatı is a relatively newer place, in terms of popularity. Although local people or residents of close big cities such as İzmir have been the usual visitors or summerhouse owners in Alaçatı, the fast development of the town has caused a fast growth in the number of entrepreneurs like restaurant or guesthouse owners, a variety of both local and foreign tourists, and a blended socio-demographic structure. Such differences in the social and economic structure of these towns may have caused the perceived differences between destination personalities of Ayvalık and Alaçatı. Since destinations can be considered as brands that provide tangible and intangible benefits, tourism marketers must consider destination personalities while strategically managing their business (Souiden et al., 2017).

The findings of this study show that consumers can be grouped into 4 clusters regarding their expectations from a summer holiday; (1) fun, excitement, and activity-oriented, (2) traveling and exploring oriented, (3) family and friends oriented, (4) relaxation, comfort, and silence-oriented consumers. Tourism marketers may differentiate their offerings in terms of these consumer groups. However, a significant difference could not be found among clusters regarding the perceived destination personalities of Ayvalık and Alaçatı. The differences between perceived sincerity, conviviality, and excitement of these two destinations are so strong that significant differences could not be observed across different consumer groups. Regardless of their expectations from a summer holiday, consumers see Alaçatı and Ayvalık as having different destination personalities. As Hosany et al. (2006) have pointed out, consumer perceptions about destination personalities have a substantial emotional component. More than $75 \%$ of the participants have seen either Ayvalık or Alaçat 1 and $66 \%$ of them have seen both destinations so the indifference among consumer groups regarding destination perceptions can be interpreted as an indicator of consumers' previous experiences and already established emotional bonds with these destinations. Destination personality has a positive impact on the relationship between tourists and destinations (Chen \& Phou, 2013). Individuals who perceive a high level of self-congruity between them and a destination are more likely to have an emotional attachment to the destination and have stronger intentions to revisit the destination (Chi et al., 2018). This finding is important for marketing managers, as perception about brand personality can override 
any other marketing effort that emphasizes different aspects of a tourism destination, such as family-focused or travelingfocused.

\section{Conclusion}

This study, which has adopted a quantitative research design, has identified significant differences between the destination personalities of Ayvalık and Alaçatı. Another finding has pointed out that consumers can be classified into four segments, depending on their expectations from a summer holiday. These segments are distinguished from one another depending on the main expectations of the consumers, like family and friends, traveling and exploring, relaxing and comfort, and fun and activity. The main limitation of this study is its small sample and convenience sampling method, so the generalizability of the results is low. Additional qualitative research may help researchers in having a deeper understanding of the reasons for varying destination personality perceptions among various consumer groups who have seen and have not seen the mentioned destinations. Future research can be conducted on the relationship between the visiting intentions of consumers and destination personality. The personality traits of tourists and the congruence between the tourists' and destination personality can also be examined in further studies. Moreover, findings can be extended by including secondary data, such as actual visitor numbers, profile, consumer preferences, and travel characteristics. After taking participant consent and confirming to ethical considerations, actual information of tourists can be analyzed and research can be expanded into a cross-cultural one that includes all tourists in the destinations. Researchers can make comparisons between the perceived destination personalities of local and foreign tourists. 


\section{REFERENCES}

Aaker, J. L. (1997). Dimensions of brand personality. Journal of Marketing Research, Vol.34 No.3, 347-356.

Alp, A. (2018). "Turkish tourism sector enjoys local holidaymaker boom over Eid holiday", http://www.hurriyetdailynews.com/turkish-tourism-sector-enjoys-local-holidaymaker-boom-over-eid-holiday136225. Accessed November 9, 2019.

Ayvalık Belediyesi (2019). "Ayvalı", http://www.ayvalik.bel.tr/index.php/component/content/article.html?id=90. Accessed August 6, 2019.

Bergman, J.Z., Rentsch, J.R., Small, E.E., Davenport, S.W., Bergman, S.M. (2012). The shared leadership process in decision-making teams. The Journal of Social Psychology, Vol.152 No.1, 17-42. DOI: 10.1080/00224545.2010.538763

Chi, C.G., Pan, L., \& Chiappa, G. (2018). Examining destination personality: Its antecedents and outcomes. Journal of Destination Marketing \& Management, Vol.9, 149-159. https://doi.org/10.1016/j.jdmm.2018.01.001

Chen, C.F. \& Phou, S. (2013). A closer look at destination: image, personality relationship and loyalty. Tourism Management, Vol. 36, 269-278.

Çetinsöz, B.C., \& Atsan, M. (2019). The process creating brand identity in destinations: A research on Anamur. Journal of Tourism Theory and Research, Vol.5 No.2, 86-98. https://doi.org/10.24288/jttr.523684

Çoban, M., \& Süer, S. (2018). Destinasyon markalaşmasında festival turizminin rolü: Alaçatı ot festivali üzerine bir araştırma. International Journal of Contemporary Tourism Research. Vol.2 No.1, 58-67. DOI 10.30625/ijctr.424439

Dedeoğlu, B.B., Van Niekerk, M., Weinland, J., \& Celuch, K. (2019). Re-conceptualizing customer-based destination brand equity. Journal of Destination Marketing \& Management, Vol. 11, 211-230. https://doi.org/10.1016/j.jdmm.2018.04.003

Dickinger, A., \& Lalicic, L. (2016). An analysis of destination brand personality and emotions: a comparison study. Information Technology \& Tourism, Vol. 15 No. 4, 317-340. https://doi.org/10.1007/s40558-015-0044-x

Dilber, I. (2007). Turizm sektörünün Türkiye ekonomisi üzerindeki etkisinin girdi-çıtı tablosu yardımıyla değerlendirilmesi. Yönetim ve Ekonomi, Vol.14 No.2, 205-220.

Dolnicar, S. (2002). A review of unquestioned standards in using cluster analysis for data-driven market segmentation, in Conference Proceedings of the Australian and New Zealand Marketing Academy Conference 2002 (ANZMAC 2002), Deakin University, Melbourne, 2002. https://ro.uow.edu.au/cgi/viewcontent.cgi?referer=\&httpsredir=1\&article=1286\&context=commpapers. Accessed 25 July 2019.

Echtner, C. M. \& Ritchie, J. B. R. (1991). The meaning and measurement of destination image. The Journal of Tourism Studies. Vol. 2 No. 2, 2-12.

Ekinci, Y. \& Hosany, S. (2006). Destination personality: An application of brand personality to tourism destinations. Journal of Travel Research, Vol.45, 127-139.

Güzel, F., Ö., Şahin, İ., Yağmur, Y., Erdem, Ö., Karasakal, S., \& Ünal, C. (2018). Antalya'nın destinasyon kişiliği ve imajına ilişkin keşfedici bir araştırma. Journal of Yasar University, Vol.13 No.50, 125-139.

Hosany, S., Ekinci, Y., \& Uysal, M. (2006). Destination image and destination personality: An application of branding theories to tourism places. Journal of Business Research, Vol.59, 638-642.

İçöz, O. (2013). Turistik ürün pazarlamasinda marka imajinin rolü ve bölgesel marka imaji yaratma (Doctoral dissertation). Retrieved from http://acikerisim.deu.edu.tr:8080/xmlui/bitstream/handle/20.500.12397/12093/348820.pdf?sequence=1

İlban, M.O., \& Kömür, T. (2019). Destinasyon markalaşmasında festival turizminin rolü: ayvalık uluslararası zeytin hasat günleri örneği. Seyahat ve Otel İsletmeciliği Dergisi, Vol.16 No.2, 274-295.

Kaplan, M.D., Yurt, O., Guneri, B., \& Kurtulus, K. (2010). Branding places: applying brand personality concept to cities. European Journal of Marketing, Vol. 44 No. 9/10, 1286-1304. https://doi.org/10.1108/03090561011062844

Kozak, M. \& Bahçe, S. (2012). Özel İlgi Turizmi, $2^{\text {nd }}$ ed. Ankara: Detay Yayıncılık.

Kerr, G., Clifford, L., \& Burgess, L. (2012). Bragging rights and destination marketing: A tourism bragging rights model. Journal of Hospitality and Tourism Management, Vol.15 No.19, 1-8.

KTB (2019). "Turizm istatistikleri”, https://yigm.ktb.gov.tr/TR-9851/turizm-istatistikleri.html. Accessed November 11, 2019.

Matzler, K., Strobl, A., Stokburger-Sauer, N., Bobovnicky, A., \& Bauer, F. (2016). Brand personality and culture: The role of cultural differences on the impact of brand personality perceptions on tourists' visit intentions. Tourism Management, Vol.52, pp.507-520. http://dx.doi.org/10.1016/j.tourman.2015.07.017

Nguyen, H., \& Bouchard, M. (2010). Patterns of youth participation in cannabis cultivation. The Journal of Drug Issues, Vol. 40 No.2, 263-293. DOI: 10.1177/002204261004000202

NTV (2019). "Turizm sektöründeki fiyat artışı yerli turistin tatil anlayışını değiştirebilir”, https://www.ntv.com.tr/seyahat/turizm-sektorundeki-fiyat-artisi-yerli-turistin-tatil-anlayisinidegistirebilir,ZUiOtme9zkStPQeSy1wzkg. Accessed May 27, 2019.

Plummer, J.T. (1985). How personality makes a difference. Journal of Advertising Research, Vol.24 No.6, $27-31$.

Souiden, N., Ladhari, R., \& Chiadmi, N. (2017). Brand personality and destination image. Journal of Hospitality and Tourism Management, Vol. 32, 54-70. 
Şchiopu, D. (2010). Applying twostep cluster analysis for identifying bank customers' profile. Buletinul UniversităNiii Petrol-Gaze din Ploieşti, Vol. LXII No. 3, 66-75.

Tokmakoğlu, A.B. (2017). “Ünü Türkiye sınırlarını aşan Alaçatı’ya gitmek için 5 neden”, https://www.cnnturk.com/seyahat/turkiye/unu-turkiye-sinirlarini-asan-alacatiya-gitmek-icin-5-neden. Accessed August 6, 2019.

Trpkoval, M. \& Tevdovski, D. (2009). “Twostep cluster analysis: Segmentation of largest companies in Macedonia”, in Proceedings of the Challenges for Analysis of the Economy, the Businesses, and Social Progress International

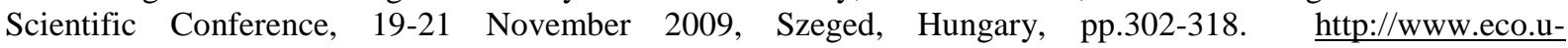
szeged.hu/english/research/scientific-publications/proceedings-of-the-challenges-for-analysis-of-the-economy Accessed 25 July 2019.

Türkmen, S. \& Köroğlu, A. (2017). "Research of destination personality: The case of Turkey and Greece", Balıkesir University The Journal of Social Sciences Institute, Vol.20 No.37, 397-429.

Ülkü, A., Solmaz, S. A., \& Barakazi, M. (2017). "Destinasyon kişiliğinin davranışsal niyetleri üzerindeki etkisi: Şanlıurfa örneği”, Uluslararası Sosyal Araştırmalar Dergisi, Vol.53 No.10, 986-994.

Wang, X., \& Yang, Z. (2008). Does country-of-origin matter in the relationship between brand personality and purchase intention in emerging economies? Evidence from China's auto industry. International Marketing Review, Vol.25 No.4, 458-474.

Yolda (2018). “Alaçatı hakkında bilmediğiniz 12 şey”, https://yoldaolmak.com/alacati-hakkinda-bilgiler.html. Accessed August 5, 2019.

Zhou, L., \& Deng, N. (2012). "Exploring the role of tourism destination personality in destination branding: A review of destination personality research", in International Conference on Services Systems and Services Management, ICSSSM Proceedings of the International Conference in Shanghai, China, 2-4 July 2012. DOI: 10.1109/ICSSSM.2012.6252274 